STUDLA HISTORYCZNE

R. LX, 2017, Z. 1 (237), s. 75-84

Katarzyna Okoniewska

Uniwersytet Adama Mickiewicza w Poznaniu

ZBRODNICZA MEDYCYNA

\title{
EKSPERYMENTY FARMAKOLOGICZNE I DOŚWIADCZENIA Z UŻYCIEM ŚRODKÓW CHEMICZNYCH PRZEPROWADZANE NA WIĘŹNIACH Z AUSCHWITZ
}

\author{
Abstract \\ CRIMINAL MEDICINE: PHARMACOLOGICAL EXPERIMENTS AND \\ THOSE EXECUTED WITH THE USE OF CHEMICAL SUBSTANCES \\ CARRIED OUT ON AUSCHWITZ PRISONERS
}

Helmuth Vetter and Friedrich Entress were responsible for pharmacological experiments undertaken in Auschwitz. Both of them tested the following: Be-1034 rutenol and 3582-rutenol in granules supplied by the pharmacological concerns (Bayer and I.G. Leverkusen). It was their task to test these medicaments according to guidelines supplied by the medical companies.

In August 1941 experiments with chemicals were initiated in Auschwitz to test the efficiency of these chemicals in killing prisoners. Hydrogen dioxide, gasoline, hydrogen, barbituric acid and phenol were injected to prisoners. In effect of these injections about 30,000 prisoners were murdered.

Key words: pharmacological experiments, phenolation, Auschwitz, Dachau, Bayer, Helmuth Vetter, Friedrich Entress, Josef Klehr

Słowa kluczowe: eksperymenty farmakologiczne, fenolowanie, Auschwitz, Dachau, Bayer, Helmuth Vetter, Friedrich Entress, Josef Klehr

Obóz Auschwitz to największy niemiecki nazistowski obóz koncentracyjny, który funkcjonował od 14 czerwca 1940 r. (przybycie pierwszego masowego transportu z Tarnowa) aż do wyzwolenia 27 stycznia 1945 r. W tym czasie zginęło w nim 1-1,5 miliona 
ludzi, z czego zdecydowaną większość stanowili Żydzi. Więźniowie żyli w ekstremalnych warunkach: cierpieli głód, zimno, byli poniżani psychicznie i fizycznie, pracowali ponad siły, byli bici, karani, rozstrzeliwani oraz poddawani eksperymentom pseudomedycznym.

Eksperymenty farmakologiczne były przeprowadzane w Oświęcimiu w różnych blokach szpitalnych, poza tym wykonywano je także w Brzezince (Auschwitz II) i w Monowicach (Auschwitz III). Dokumentacja oryginalna jest niekompletna, jednak wynika z niej, że doświadczenia farmakologiczne rozpoczęły się w Oświęcimiu jesienią 1941 r., czyli zaraz po przybyciu do obozu Helmutha Vettera, i trwały z różnym nasileniem do 1944 r. Doświadczenia te były prowadzone na zlecenie koncernów farmaceutycznych i według ich instrukcji.

\section{HELMUTH VETTER}

Helmuth Vetter urodził się w 1910 r. w Turyndze. Studia odbył na Uniwersytecie im. Johanna Wolfganga Goethego. W październiku 1933 r. wstapił do SS. Od 1936 r. pracował w szpitalu Rastpfuhl w Saarbrücken, a w 1938 r. został zatrudniony w niemieckiej firmie I.G. Leverkusen, kilka lat później pracował także dla I.G. Farbenindustrie oraz Bayer. Był lekarzem obozowym w KL Dachau, KL Auschwitz i KL Mauthausen. Na więźniach testował przede wszystkim tolerancję preparatów farmakologicznych (zwłaszcza Be1034, rutenolu i 3582-rutenolu granulatu), ich wpływ na organizm oraz przeprowadzał zabiegi bez medycznego uzasadnienia ${ }^{1}$. Za wydanie pozytywnej opinii o leku pobierał premię od koncernu I.G. Farbenindustrie. Vetter eksperymentował nie tylko z lekami, ale także z samym tyfusem. Osobom całkowicie zdrowym podawał kroplówki dożylne o objętości 1-10 $\mathrm{cm}^{3}$ krwi od chorych, celem zarażenia ich, a tym samym stworzenia możliwości obserwacji reakcji ich organizmów: określenia, ile czasu rozwija się choroba i jaki jest jej przebieg. Efektem doświadczenia była śmierć wszystkich więźniów poddanych temu eksperymentowi.

Badanie tolerancji leków zaczęło się w modelowym KL Dachau. Vetter był zachwycony możliwościami, jakie daje mu praca w obozie, o czym wspomniał w liście do kolegów z firmy farmaceutycznej Leverkusen: „Możecie sobie wyobrazić, z jakim zapałem rzuciłem się w wir nowych obowiązków, zwłaszcza że mam możliwość praktycznego wypróbowania także naszych preparatów. [...] Gdy porównuję wszystko z poprzednim okresem, wydaje mi się, że trafiłem do raju².

1 Oswiecim w oczach SS. Rudolf Höss, Perry Broad, Johann Paul Kremer, red. J. Bezwińska, D. Czech, tłum. E. Kocwa, J. Rawicz, Oświęcim 2007, s. 233.

2 E. Klee, Auschwitz: Medycyna III Rzessy i jej ofiary, tłum. E. Kalinowska-Styczeń, Kraków 2011, s. $275-276$. 
W Dachau głównym zadaniem Vettera było przeprowadzenie eksperymentów z eleudronem i sulfapyridinem. Pierwszy z nich miał być skuteczny w walce z rzeżączką, zapaleniem płuc i opon mózgowych, a także w przypadku ropniaków i czyraków. Drugi lek był uważany za najlepszy preparat również w walce z rzeżączką, jednak podawany był także w przypadku zapalenia płuc i opon mózgowych. Instrukcje, które otrzymywał od firmy Vetter, były bardzo konkretne, a zawarte w nich informacje mówiły o potrzebie porównawczego prowadzenia leczenia płuc i sprawdzenia działania obu substancji: „W tym kontekście interesuje nas także, jaką wartość terapeutyczną ma doodbytnicze podanie sulfapyridinu i eleudronu"3.

Do Auschwitz Vetter przybył jesienią 1941 r. Były lekarz-więzień Stanisław Kłodziński wspominał rozpoczęcie eksperymentów farmakologicznych w taki sposób:

Vetter doręczył mi różne preparaty, między innymi preparaty wyrobu I.G. Farbenindustrie w Leverkusen, oznaczono je jako Be 1034. Oświadczył, że są to preparaty próbne, że były one już wypróbowane w innych obozach, że nie są szkodliwe i powinny dać najprawdopodobniej pozytywne wyniki w stosowaniu przeciw tyfusowi plamistemu4

Preparat Be-1034 stosowano w przypadku tyfusu plamistego, brzusznego i róży ${ }^{5}$. Dla tego leku wydano następujące instrukcje co do sposobu dawkowania:

1) tabletki o gramaturze $0,25 \mathrm{~g}$ należało podawać 4 razy dziennie przez $13 \mathrm{dni}^{6}$,

2) po tym czasie zwiększano częstotliwość od 6 aż do 12 tabletek dziennie w zależności od przypadku?

3) jeżeli aplikowano zastrzyki dożylne lub domięśniowe: podawano iniekcję 2 razy dziennie po $5 \mathrm{~cm}^{3}$ przez cały okres gorączki, a następnie zmieniano liczbę zastrzyków do 4 razy dziennie 8 .

Vetter zlecił prowadzenie bardzo dokładnych obserwacji. Interesowało go zwłaszcza: zachowanie się języka (wysychanie, obłożenie), zmiana temperatury ciała, tempo akcji serca, zachowanie się centralnego systemu nerwowego, układu siateczkowo-błonkowego

\footnotetext{
Ibidem, s. 277.

4 Archiwum Państwowego Muzeum Auschwitz-Birkenau [dalej cyt.: APMA-B], Proces Hössa, t. 59, k. 64.

5 Ibidem, k. 66-67.

6 Średni czas występowania gorączki.

7 Zarówno rodzaj leku, jak i dawka były dobierane indywidualnie.

8 APMA-B, Proces Hössa, t. 59, k. 65-66.
} 
i wynik analizy moczu? . W wypadku śmierci należało natychmiast dokonać sekcji zwłok i ocenić, jakie zmiany zaszły w narządach.

Były lekarz-więzień Władysław Fejkiel stosował na polecenie Vettera preparat Be-1034 na 50 więźniach chorujących na tyfus. Lek jednak nie dawał zadowalających wyników, więc został zastapiony medykamentem 3582 (zwanym inaczej rutenolem granulatem), który miał wyraźny wpływ na podniesienie temperatury ciała: w 74\% przypadków dopiero po 3-4 dniach zaczynała ona spadać, w 12\% wróciła do normalnej, jednak dopiero pod koniec trwania kuracji, a w przypadku $14 \%$ nie zauważono żadnych powiązań ${ }^{10}$.

Warto zaznaczyć, że dokonywano także eksperymentów mających na celu porównanie działania rutenolu z rutenolem granulatem. Vetter miał sprawdzić, czy lek w formie granulatu był lepiej przyswajany przez organizm. W tym celu otrzymał 25 opakowań tabletek i 25 paczek z granulatem:

Prosimy uprzejmie o podanie ich każdorazowo grupie dwudziestu pięciu osób doświadczalnych i odnotowanie, czy zażycie preparatu na pełny żołądek z duża ilościa płynu albo zupy powoduje, że po przyjęciu kilku dawek pojawiaja się wymioty, ewentualnie jaki procent osób doświadczalnych toleruje sześć lub więcej tabletek czy odpowiednich porcji granulatu ${ }^{11}$.

Eksperyment przeprowadzono na 50 więźniach. W 78\% przypadków tabletki zostały zwymiotowane, a pozostali byli podczas leczenia nieprzytomni. Wszystkim osobom poddanym doświadczeniu pogorszył się wzrok i słuch. Efektem była śmierć 15 osób ${ }^{12}$. Po tym, jak lek w formie tabletek został uznany za bezwartościowy, wykorzystano do następnych doświadczeń granulat 5- i 10-procentowy, dokładniejsze badania zostały jednak przeprowadzone w Buchenwaldzie przez tamtejszych lekarzy SS.

Preparat 3582 stosowano zarówno w przypadku tyfusu, jak i gruźlicy. Lek działał negatywnie na samopoczucie więźniów chorujących na gruźlicę. Po przyjęciu dawki występowały skutki uboczne w postaci wymiotów, utraty apetytu i spadku wagi ${ }^{13}$. Z 50 więźniów, na których testowano lek, zmarło 15 osób:

- 6 osób zmarło wskutek osłabienia mięśnia sercowego,

- 6 z powodu znacznego spadku masy ciała,

9 S. Kłodziński, Zbrodnicze dośniadczenia farmakologiczne na wię́niach obozu koncentracyjnego w Ośmięcimiu, „Przegląd Lekarski” 1965, nr 1, s. 44.

10 APMA-B, Proces Załogi, t. 59 I, s. 62.

11 E. Klee, op. cit., s. 291.

12 Ibidem, s. 295-296.

13. S. Kłod zińs ki, Zbrodnicze eksperymenty z zakeresu gruźlicy dokonywane w hitlerowskich obozach koncentracyjnych w crasie II wojny światowej, „Przegląd Lekarski” 1962, nr 1a, s. 80. 
- 2 na skutek zapalenia mózgu,

- $1 \mathrm{w}$ wyniku silnej goraczzidi ${ }^{14}$.

Z kolei podczas leczenia tyfusu łagodniały bóle głowy, stawów i mięśni. Suchość jamy ustnej, języka i podniebienia zostawały takie same. $62 \%$ chorych było przytomnych w czasie leczenia, 26\% odzyskiwało przytomność w trakcie leczenia, 12\% chorych było nieprzytomnych przez cały czas prowadzenia eksperymentu ${ }^{15}$.

Jedynym preparatem, który dał wynik pozytywny w walce z tyfusem, był periston ${ }^{16}$. Lek pojawił się w obozie w listopadzie 1942 r. i jego głównym zadaniem było wspieranie krążenia oraz redukcja objawów mózgowych towarzyszących tyfusowi. Eksperyment miał odpowiedzieć na pytania:

1) Czy krążenie zostało wzmocnione; jeśli tak, to na jaki okres?

2) Jak wpłynął lek na obrzęki mózgu w porównaniu z zastrzykami z roztworu soli? ${ }^{17}$ Periston podawano w formie zastrzyków dożylnych i zastosowano jedynie u 5 chorych: u 4 osób w momencie rozwinięcia się choroby, a u jednej osoby w 9 . dniu, jednak chory zmarł wskutek osłabienia mięśnia sercowego. Na podstawie obserwacji wyciągnięto następujące wnioski:

- nie stwierdzono negatywnego działania peristonu na organizmy więźniów,

- lek poprawiał ogólne samopoczucie chorych, którzy chętnie go przyjmowali: łagodził bóle głowy, działał przeciwzapalnie,

- nie miał wpływu na czas trwania choroby,

- powodowal podwyższenie ciśnienia krwi,

- spadek wagi był 10-krotnie niższy ${ }^{18}$.

Vetter prowadził identyczne doświadczenia w KL Mauthausen, jednak, jak sam oznajmiał, w przypadku gruźlicy wyniki były bardzo dobre, a więźniowie przybierali na wadze ${ }^{19}$.

\section{FRIEDRICH KARL ENTRESS}

Friedrich Entress urodził się 8 grudnia 1914 r. w Poznaniu. Został wcielony do Waffen-SS jako członek samoobrony. Początkowo pełnił funkcję lekarza obozowego w KL Gross-

\footnotetext{
APMA-B, Proces Załogi, t. 59, k. 61.

15 S. Kłodziński, Zbrodnicze doświadczenia farmakologiczne..., s. 42.

${ }_{16}$ J. Mikulski, Eksperymenty farmakologiczne w obozie Oświęcim-Bržeżinka, „Zeszyty Oświęcimskie” 1967, nr 10, s. 7.

17 E. Klee, op. cit., s. 288.

18 S. Kłodziński, Zbrodnicze doświadczenia farmakologiczne..., s. 45.

19 APMA-B, Proces Załogi, t. 59, k. 60.
} 
-Rosen w okresie od 3 stycznia do 10 grudnia 1941 r. 11 grudnia 1941 r. został przeniesiony do KL Auschwitz jako lekarz obozowy w Brzezince i w Monowicach ${ }^{20}$. Entress przeprowadzał doświadczenia medyczne związane z durem wysypkowym, eksperymenty chirurgiczne i farmakologiczne. Podobnie jak Helmuth Vetter robił operacje zbędne, ponieważ chciał zdobyć doświadczenie jako lekarz. W tym celu sztucznie łamał kości, by opanować technikę nakładania opatrunków usztywniających, operował wyrostki itp. ${ }^{21}$ Od grudnia 1943 r. był lekarzem w Gusen.

Były więzień Rudolf Diem zeznał, że Entress wykonywał zastrzyki dożylne i domięśniowe, w wyniku których zaczęły pojawiać się objawy zakażenia ogólnego/miejscowego oraz ropowice. Lekarz zajmował się więźniami osobiście przez 10 dni: przemywał rany, nakładał odpowiednie maści/płyny, a następnie przekazywał chorych pod opiekę lekarzy-więźniów. Entress nakładał na rany opatrunki nasączone iperytem, co doprowadzało do powstawania martwic poiperytowych. Miejsca zmienione były fotografowane, a następnie wycinane. W związku z brakiem leków leczenie przedłużało się i więźniowie często umierali, jednak ci, którzy przeżyli, borykali się z niedowładem obwodowym²2.

Kolejny były więzień Władysław Tondos opowiadał, że na zlecenie Entressa w lipcu 1943 r. wydzielono 20 osób chorych na gruźlicę, które postanowiono leczyć za pomoca rutenolu. Początkowo otrzymywali oni preparat w formie proszku, po czym zmieniono go na granulki i dawkowano po 3 łyżeczki dziennie przez $5 \mathrm{dni}^{23}$. Po tym czasie następowała tygodniowa przerwa. Entress polecił, by chorym wykonywać badania rentgenowskie, badania moczu i wydzieliny wykrztuszanej z dróg oddechowych. Sekcje zmarłego więźnia przeprowadzał na polecenie Entressa lekarz-więzień prof. dr Jan Olbrycht. Eksperyment przeżyło zaledwie 4 więźniów ${ }^{24}$.

\section{FENOLOWANIE}

$\mathrm{Na}$ początku istnienia obozów śmiertelność nie była zjawiskiem masowym. Przykładowo w KL Dachau zabijano więźniów przy pracy na różne, nieraz dość wymyślne sposoby: oprócz wieszania i strzelania do więźniów w trakcie ucieczki topiono ich w kałużach i zmuszano do skakania z różnych wysokości. Z czasem zaczęto doskonalić narzędzia śmierci: niepełnosprawnych wysyłano do Hartheim koło Linzu w Austrii i tam gazowano, a w rewirze uśmiercano jeńców zastrzykami.

\footnotetext{
20 Oświęcim w oczach SS..., s. 215.

21 APMA-B, Wspomnienia, t. 172, s. 140-141.

22 Ibidem, s. 137-138.

23 S. Kłodziński, Zbrodnicze doświadczenia farmakologiczne..., s. 43.

24 J. Mikulski, op. cit., s. 15.
} 
W sierpniu 1941 r. w Auschwitz zaczęto eksperymentalnie podawać zastrzyki z wody utlenionej, benzyny, wodoru, ewipanu i fenolu w celu sprawdzenia ich skuteczności w uśmiercaniu więźniów ${ }^{25}$. Śmierć zadaną poprzez zastrzyk nazywano „szpilowaniem”, „szprycowaniem” lub „fenolowaniem”. Do eksperymentów wybierano osoby niezdolne do pracy ${ }^{26}$, więźniów skazanych na śmierć przez Oddział Polityczny, dzieci, zwłaszcza noworodki, które uznawano za bezwartościowe i uciążliwe dla życia obozowego. Miejscem egzekucji była początkowo kostnica. Szpilowanie zdarzało się też w bloku chirurgicznym, później jednak utworzono specjalną salkę w bloku $20^{27}$.

Najefektywniejszą substancją okazał się fenol, który miał także inne zalety: był tani, łatwy w użyciu, nie niszczył szkła ani metalowych części strzykawki, działał żrąco i powodował denaturację białek. W okresie początkowym stosowano zastrzyki dożylne, jednak śmierć zadana poprzez wstrzyknięcie fenolu bezpośrednio w serce następowała szybciej. Wstrzykiwano 30-procentowy roztwór fenolu ${ }^{28}$. Była to substancja tak silna, że na zwłokach powstawała ciemna plamka od spalenia tkanki w okolicach śladu wbitej igły. Zabieg fenolowania wykonywali: dr Hans Wilhelm König, dr Horst Schumann, dr SS Horst Fischer, dr SS Georg Franz Mayer, dr SS Josef Mengele, dr SS Kurt Uhlenbrock, SDG Oberscharführer Josef Klehr, SDG SS Unterscharführer Emil Hantl, SDG SS Unterscharführer Hans Niedzwicki oraz SDG SS Unterscharführer Herbert Scherpe.

Prócz wyżej wymienionych lekarzy i sanitariuszy SS mordowali także więźniowie: Mieczysław Pańszczyk, Alfred Stesel, Feliks Walentynowicz, Jerzy Szymkowiak i dr Leibus Landau ${ }^{29}$. Z zeznań Stanisława Głowy wynika, że sam Mieczysław Pańszczyk uśmiercił w ciagu 2 lat ok. 15 tysięcy więźniów ${ }^{30}$.

Josef Klehr zrelacjonował, w jaki sposób zabijał więźniów:

Trudno było trafić w żyły i wtedy jeden z lekarzy SS wpadł na pomysł, by fenol wstrzykiwać bezpośrednio do komory serca. Wymacywałem między żebrami serce. Kandydaci na śmierć byli pojedynczo wprowadzani do pokoju zastrzyków i sadzani na stołku, tak że potem zapadali się w sobie, nie spadając na podłogę. Potem zabierano ich do kostnicy, a stamtąd [...] do krematorium. Oni wiedzieli, co ich czeka, ale się nie bronili. Byli całkowicie wycieńczeni.

25 H. Langbein, Auschwitzprzed sqdem. Proces we Frankfurcie nad Menem 1963-1965. Dokumentacja, Oświęcim 2011, s. 529.

26 Podczas selekcji ostateczny głos miał wielokrotnie wspomniany w tekście Friedrich Entress odpowiedzialny za eksperymenty farmakologiczne.

27 APMA-B, Oświadczenia, t. 36, s. 3.

28 Ibidem, k. 3.

29 S. Kłodziński, Fenol w KL. Auschwitz-Birkenau, „Przegląd Lekarski” 1963, nr 1a, s. 65.

30 APMA-B, Oświadczenia, t. 36, k. 3. 
Pozostały z nich same szkielety. [...] Raz albo dwa razy w tygodniu szedłem do aptekarza, aby pobrać fenol ${ }^{31}$.

Zabieg szpilowania wykonywany przez Mieczysława Pańszczyka wyglądał nieco inaczej. Dwóch sanitariuszy przekładało za głowę więźnia jego rękę i zasłaniało mu oczy, przechylając go do tyłu, a następnie poprzez podłożenie kolana pod kręgosłup powodowali wypięcie piersi więźnia. Wówczas Pańszczyk wbijał igłę w klatkę piersiową, po czym oddawał Klehrowi strzykawkę i przygotowywał kolejną dla następnej osoby. Jeżeli więźniowie krzyczeli, wówczas Klehr kazał im podnieść lewą rękę do góry i zasłonić sobie usta. Chwalono się tym, że w ciągu minuty można było zabić nawet 3 więźniów. Sam Klehr zeznal, że zwykle szpilowano 2 razy w tygodniu, za każdym razem do 15 osób. Tak było przez 2-3 miesiące ${ }^{32}$. Jednak nie każde szpilowanie kończyło się śmiercią więźnia. Zdarzyło się, że bezpośrednio po fenolowaniu jednemu z więźniów udało się wstać i usiąść na ławce. Wtedy jednak podszedł do niego Klehr i zaszpilował go drugi raz. Skazani dość często nie zdawali sobie sprawy z tego, co ich czeka. Obrazuje to fragment zeznania Johanna Paula Kremera: „Klehr miał na sobie kitel lekarski, opukał kobietę i powiedział: Pani choruje na serce - i dał jej zastrzyk w serce. Ona zmarła natychmiast. Wtedy uciekłem. To była solidna strzykawka, chyba z 10 albo $20 \mathrm{~cm}^{3,33}$.

Zwłoki nabierały barwy różowo-sinej, a spojówki były przekrwione. Ciała sztywniały kilka godzin później. Fenol podany w ilości 10-15 ml wywoływał śmierć w ciąu 15 sekund $^{34}$. Dla porównania warto zaznaczyć, że przy użyciu wodoru czas zgonu osiagał ok. 20 minut $^{35}$. Szacuje się, że w wyniku zaszpilowania zmarło ok. 30 tysięcy więźniów ${ }^{36}$.

Reasumując, stosowanie wszystkich powyższych leków i substancji chemicznych było zbrodniczym eksperymentem pseudomedycznym, ponieważ osoby poddawane badaniom nie zgłaszały się na nie dobrowolnie. Używano wobec nich nacisku i podstępu, obiecując, że po wykonaniu doświadczenia zostaną zwolnione z obozu. Dla więźniów udział w którymkolwiek z eksperymentów był niemalże równoznaczny z wyrokiem śmierci. Należy podkreślić, że głównym celem tych doświadczeń nie było dobro więźnia, ale jedynie obserwacja działania konkretnych preparatów, nawet jeśli szkodziły one chorym i prowadziły do ich zgonu. Lekarze nie przerywali badań w okresach krytycznych i dalej podawali leki, obserwując powolną śmierć więźniów, by w końcu przeprowadzić sekcję zwłok w celu wysnucia na jej podstawie odpowiednich wniosków.

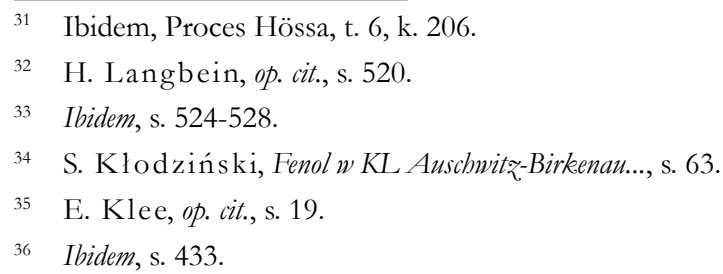


Osoby odpowiedzialne za wykonywanie eksperymentów medycznych zostały osądzone w procesach załóg. Friedrich Entress został skazany na karę śmierci w procesie załogi obozu Mauthausen i Gross-Rosen. Wyrok wykonano 28 maja 1947 r. ${ }^{37}$ Helmuth Vetter podzielił jego los. Został skazany w procesie załogi Mauthausen i powieszony w więzieniu Landsberg 2 lutego $1949 \mathrm{r} .^{38}$ Victor Capesius, aptekarz odpowiedzialny za zamawianie fenolu, był sądzony w drugim procesie członków załogi Auschwitz i został skazany na 9 lat pozbawienia wolności, jednak więzienie opuścił po niespełna 3 latach. Josef Klehr został schwytany przez wojska amerykańskie i skazany na pobyt w obozie pracy $^{39}$. Zwolniono go w $1948 \mathrm{r}$. Aresztowany ponownie w 1960 r., dostał karę 15 lat pozbawienia wolności. Zmarł w $1988 \mathrm{r}$.

\section{Bibliografia}

Materiały archiwalne:

Archiwum Państwowego Muzeum Auschwitz-Birkenau w Oświęcimiu

Oświadczenia, t. 36.

Proces Hössa, t. 6, 59 .

Proces Załogi, t. 59 I.

Wspomnienia, t. 172.

\section{Opracowania:}

Klee E., Auschwitz: Medycyna III Rzeszy i jej ofiary, tłum. E. Kalinowska-Styczeń, Kraków 2011. Kłodziński S., Fenol w KL Auschwitz- Birkenau, „Przegląd Lekarski” 1963, nr 1a, s. 63-65.

Kłodziński S., Zbrodnicze doświadczenia farmakologiczne na wię́niach obozu koncentracyjnego w Oświęcimiu, „Przegląd Lekarski” 1965, nr 1, s. 42-44.

Kłodziński S., Zbrodnicze eksperymenty z zakeresu gruślicy dokonywane w bitlerowskich obozach koncentracyjnych w czasie II wojny swiatowej, „Przegląd Lekarski” 1962, nr 1a, s. 80.

Langbein H., Auschwitzprzed sqdem. Proces we Frankfurcie nad Menem 1963-1965. Dokumentacja, Oświęcim 2011.

Mikulski J., Eksperymenty farmakologiczne w obozie Ośnięcim-Brzezinka, „Zeszyty Oświęcimskie” 1967, nr 10, s. 7-15.

Ośniecim w oczach SS. Rudolf Höss, Perry Broad, Johann Paul Kremer, red. J. Bezwińska, D. Czech, tłum. E. Kocwa, J. Rawicz, Oświęcim 2007.

Strzelecka I., Zbrodnicza medycyna. Eksperymenty medyczne w KL Auschwitz, Oświęcim 2008, Głosy Pamieci 2.

37 I. Strzelecka, Zbrodnicza medycyna. Eksperymenty medyczne w KL Auschwitz, Oświęcim 2008, s. 128, Gtosy Pamieci, 2.

38 Jewish Virtual Library, The Dachau Trials: Mauthausen-Gusen Cases, case no. 000-50-5-31 (US vs Karl Glas et al.), 12 August 1947, [on-line:] http://www.jewishvirtuallibrary.org/jsource/Holocaust/ dachautrial/531.pdf.

39 http://www1.jur.uva.nl/junsv/brd/brdengfiles/brdeng595.htm - II 2017. 


\section{Źródła internetowe:}

Jewish Virtual Library, The Dachau Trials: Mauthausen-Gusen Cases, case no. 000-50-5-31 (US vs Karl Glas et al.), 12 August 1947, [on-line:] http://www.jewishvirtuallibrary.org/jsource/ Holocaust/dachautrial/531.pdf.

http://www1.jur.uva.nl/junsv/brd/brdengfiles/brdeng595.htm 